\title{
Reading Rousseau in Spanish America during the wars of independence (1808-1826)
}

\author{
Nicola Miller
}

Rousseau was cited widely, if sometimes anonymously, throughout Spanish America during the wars of independence, in proclamations, political pamphlets, manifestos, newly founded periodicals and even in draft constitutions. The Social Contract was probably the most important single theoretical statement in Spanish America during the 1810s, a touchstone text for the key questions of the age. Yet few of Rousseau's ideas featured in the actual founding documents of the new republican order.1 At the close of long, destructive wars, with the threat of persistent lawlessness looming, the majority of Spanish American constitutionalists opted for delegated sovereignty, representative government and separation of the three powers, a model associated more with Montesquieu. ${ }^{2}$ Nor, with rare

${ }^{1}$ Spanish American constitutionalists drew on a wide range of sources from political philosophy, but the resulting documents were mainly based upon the existing modern republican constitutions of France, usually the 1791 version; Spain (Cádiz), 1812; and the United States, 1787. An important source on the United States was the collection of translations by Manuel García de la Sena: La independencia de la Costa Firme justificada por T. Paine treinta años há (Philadelphia: no publisher stated, 1811), which included extracts from Thomas Paine, the Declaration of Independence, the Articles of Confederation, plus the 1787 Constitution and the constitutions of various states.

2 Rousseau's essay Considerations on the Government of Poland (written 17701771, published 1782), which contained much material of direct relevance to cautious republicans, was apparently not translated into Spanish at this time. It is a matter of 
exceptions, did Spanish Americans accept Rousseau's views on freedom of belief, let alone his ideal of a civic religion: nearly all of the documents from the independence era, even the most Jacobin, proclaimed allegiance to the Catholic faith, which duly became the established Church in all of the new states. ${ }^{3}$ Although Spanish American nation-builders agreed with him that public education was central to building a modern republic, in most of the independent states Rousseau's idealistic vision of independent personal development was set aside in favour of elementary schools and prosaic Lancastrian teaching methods as the most likely to be effective given prevailing shortages of teachers, buildings, books and equipment. ${ }^{4}$ Even the most famous myth about Rousseau and Spanish America is just that: the appealing image of the great liberator, Simón Bolívar, as a Spanish American Émile,

dispute whether Rousseau rejected representative government (as is implied by the small scale of the ideal republic envisaged in $S C$ ) or delegated sovereignty. The former view was promoted by his Spanish translator, José Marchena.

${ }^{3}$ A striking example is the constitution agreed at Apatzingan, Mexico, in 1814, which was full of Rousseauvian terminology (as discussed below) but proclaimed loyalty to Catholicism in its first article. 'Decreto constitucional para la libertad de la América Mexicana, sancionado en Apatzingan (22 de octubre de 1814)', in Ernesto de la Torre Villar, La Constitución de Apatzingan y los creadores del estado mexicano (Mexico City: UNAM, 1964), 380-382. Two significant exceptions were Bernardo O’Higgins in Chile and José Artigas in what is now Uruguay, both of whom advocated freedom of worship.

4 There are elements of Rousseau's theories in Spanish American curricula throughout the nineteenth century, for example physical education (part of the ancient Greek conception of citizen virtue), but that would be true of virtually any country with a public education policy. 
steered towards authentic self-expression in bucolic encounters with his tutor Simón Rodríguez, sadly does not stand up to scrutiny.5

So the question arises: if Rousseau's political theories were not implemented in Spanish America, how and why did his ideas matter there? How are we to understand the ubiquity of his presence in political discourse and his equally striking absence from political outcomes in Spanish America? His unhesitating denunciations of enforced rule evidently lent coherence and, even more importantly, moral weight to the cause of independence, which took several years to gather sustained momentum and critical mass. But was there anything beyond the fact that the rhetorical brilliance of his writing compelled many individuals to express certain widely shared ideas, above all passion for liberty and loathing of tyranny, in his memorable words?

I think that there was: namely, that Rousseau was interpreted as expressing - for good or ill - the possibility of fundamental transformation, not only of institutions and structures, but also of social relations, cultural practices and individual ways of being.6 No other thinker (with the possible exception of Thomas Paine) went so far in developing a voluntaristic conception of a new social order. As I will illustrate below, the presence of a distinctively Rousseauvian vision of transformation, persuasively articulated by certain key figures in the independence movements, had significant consequences at certain crucial

${ }^{5}$ Jesús Andrés-Lasheras, Simón Rodriguez: Maestro Ilustrado y Político Socialista (Universidad Nacional Experimental Simón Rodriguez/Ediciones Rectorado: Caracas, 2004), 103-105.

${ }^{6}$ Transformation is one among several factors identified as accounting for Rousseau's prominence in Latin America in Boleslao Lewin's study, Rousseau en la independencia de Latinoamérica (Buenos Aires: Ediciones Depalma, 1980), 5. 
moments during the early stages of the independence movements (c. 1810-1813). It also contributed, I will argue, to a legacy of radical political projects, which, despite failing themselves, helped to inspire later, more successful initiatives. I will go on to suggest two other, related ways in which readings of Rousseau stimulated Spanish American thinkers to develop ideas and practices that had lasting effects: the prospect of the Americas as a force for world-historical regeneration and the embedding of a particular archetype of the intellectual based on the writer as an agent of social transformation.

The question of how Rousseau was interpreted in Spanish America is germane both to empirical debates about the role of Enlightenment ideas in the history of the Spanish American wars of independence and to methodological debates in intellectual history. Historians of ideas have long debated the role of Rousseau in the French Revolution, but have paid far less attention to analysing how he was read in the area of the world where republicanism next took root. Historians of the Spanish American independence wars tend to concur - perhaps too readily - that the political ideas of the Enlightenment played no causative role in events that are mainly attributable to a political crisis in Europe, although such ideas are usually deemed to have provided a framework for the articulation of a new political order. There is a widespread, related assumption that those who were familiar with Enlightenment thinking were supporters of independence, and that those who were not were loyalists. The evidence on the reception of Rousseau, however, casts doubt on all of these arguments.

It was not only supporters of independence who cited Rousseau in defence of their cause, but also its opponents. For example, Manuel de Vidaurre (1773-1841) was known as 'the Peruvian Rousseau', yet he continued to advocate Spanish rule until the very last 
stages of the lengthy Peruvian war of independence, contending - as had Rousseau with respect to ideal republics - that it would be impossible to establish a democratic republic given the stark inequalities in his country.7 Moreover, some critics of Rousseau were in favour of independence, such as the Mexican friar Servando Teresa de Mier, who came to see a break with Spain as inevitable but feared an alien egalitarianism he thought could only be implemented by force, and sought to preserve the institutions of creole society (especially the Church) as bulwarks against lawlessness. ${ }^{8}$ The Catholic clergy, like almost everybody else, was divided over Rousseau: some clerics, especially among the more senior, denounced him, but many of his staunchest advocates were priests or friars. It is testimony to his prominence in the public debates of the era that even people who were profoundly out of sympathy with him felt compelled to cite him or at least borrow his language to authorise their own arguments, either because they were engaged in a polemic with one of his advocates or simply because his name carried such weight. . $^{9}$ Even the explicitly anti-Jacobin Agustín de Iturbide, briefly emperor of Mexico (1822-1823), publicly justified his actions with reference to 'the general will'. In short, Rousseau was invoked by some surprising people in support of some surprising arguments, and it is not

${ }^{7}$ Manuel de Vidaurre, Cartas americanas, políticas y morales (Philadelphia: Juan F. Hurtel, 2 vols., 1823).

8 Servando Teresa de Mier, Historia de la revolución de la Nueva España, 1813, extract in José Luis Romero and Luis Alberto Romero, eds., Pensamiento político de la emancipación, 2 vols. (Caracas: Biblioteca Ayacucho, 1977), vol. II, 46-52, 50.

${ }^{9}$ For example, Chilean cleric Tadeo Silva oversimplified a passage from Émile, changing its sense, in support of his argument that fanaticism was less of an evil than irreligion, in the course of a polemic against the Rousseauvian priest, Camilo Henríquez, about reform of the religious orders. Tadeo Silva, El Observador Eclesiástico de Chile (Córdoba: Imprenta de la Universidad, 1824), no. 8, 9 Aug. 1823, 100; cf Émile, book IV, 84. 
possible to map reference to his ideas onto political and/or religious divides in Spanish America in any predictable way. Instead, there were ardent champions and engaged critics, wary opponents and virulent detractors, for all of whom Rousseau was an inescapable cultural reference point. This suggests that there was overall no simple equivalence between Enlightened Independentistas and reactionary loyalists.

The modern debate about whether advocates of independence drew mainly on European Enlightenment thinkers or on scholastics such as Francisco Suárez misses the main features of Spanish American intellectual life at the time, 10 namely its sheer diversity and changeability. The thought of the philosophes was by no means the only source of ideas and inspiration for Spanish Americans as they sought to negotiate the unprecedented situations created by Napoleon's deposition of Fernando VII from the Spanish throne. Works of scholasticism - itself a far more varied tradition than is usually acknowledged were still read, alongside accounts of modern scientific developments, treatises on natural law and elaborations of creole patriotism, all of which, plus the various French and US Constitutions and related commentaries, contributed to the political repertoire of Spanish American independence. Moreover, different sources were drawn upon - and combined and re-combined with one another - as seemed most appropriate to a rapidly changing political situation.

In a context in which a great variety of sources was drawn upon, it is always potentially misleading to focus upon a single thinker. It is not always easy to distinguish what was specifically derived from Rousseau in the wider field of 'Enlightenment thought'

${ }^{10}$ For a summary of these debates, see José Carlos Chiaramonte, La Ilustración en el Río de la Plata (Buenos Aires: Editorial Sudamericana, 2007), 46-48. 
that featured prominently in public discourse after 1808 and became the requisite cultural capital of any educated Spanish American. Rousseau was often invoked as one of a troika of 'moderns', usually with Montesquieu, often with Voltaire, sometimes with Locke, Raynal or Filangieri. A good many of the ideas that have been attributed to 'Rousseau's influence' liberty as the foundation of good government, the social contract, republicanism, virtuous citizenship - could be found in many of the European works circulating in Spanish America during the independence era. Several of the texts that have been claimed as Rousseauvian turn out, on closer scrutiny, to be precisely examples of how the ideas of various philosophers were combined, often with local sources, to respond to the particular circumstances in which they were written. A full account of how Rousseau was read in Spanish America during the early nineteenth century would require analysis of how various other thinkers were read, above all Montesquieu. In the early stages of the independence struggles, Rousseau's arguments about liberty as a natural right and his denunciations of colonial rule were combined with Montesquieu's case that laws should be based on the customs and practices of a particular society. Neither argument worked in isolation: it was only together that they justified the break from Spain. Advocates of independence needed both Rousseau and Montesquieu.

These textual collages provide a clue about how to explore what happened when ideas travelled. The history of movement of ideas from Europe to Spanish America, with its distinctive mix of European, indigenous and African cultures, highlights a range of questions that may well need to be addressed even when ideas moved between more closely comparable societies. In thinking about the cultural context into which the ideas were moving, we need to ask not only about other texts available but also about a far 
broader range of values, assumptions and practices that may have shaped how they were interpreted. The history of dissemination is of course crucial, but so too is the reputation of the author. Rousseau in Spanish America provides a telling example of this point: his public image in the region before 1808 is a significant factor in explaining the role of his ideas subsequently.

\section{A whiff of embers: Rousseau's reputation in Spanish America}

Rousseau's works were proscribed in Spanish America before 1808 by an Inquisition ban dating back to 1764 . Nonetheless, copies of most of them arrived in the region shortly after their publication in Europe.11 They were smuggled in by French émigrés, diplomats, intellectually curious clerics and other members of the educated minority who read French, visited Europe and regarded European culture as their own. Societies that had long lived with censorship had correspondingly well-established mechanisms for evading it: underground circulation of handwritten copies, extracts slipped into other volumes, books that glossed or summarised the ideas of banned authors without naming them. In any case, the Bourbon monarchy was itself committed to reform of the Spanish state, including the reduction of the political power of the Catholic Church and the courts of the Inquisition. It is clear that there was significant local variation in the extent, coherence and effectiveness of their initiatives, which were felt strongly in New Spain or Peru, far less so in New Granada

11 Jefferson Rea Spell, Rousseau in the Spanish World before 1833 (Austin: University of Texas Press, 1938), 129-139. 
or Chile. Even so, overall there is little doubt that the Declaration of Free Trade in 1778 opened up new opportunities for the movement of people and goods, including books, between the old world and the new; more liberal viceroys turned a blind eye to - or even encouraged - the discussion of modern scientific ideas in institutions of learning; and the Sociedades Económicas de los Amigos del País were founded to encourage the adoption of modern political economy.12 Until the 1790 s, then, Rousseau was one among many Enlightenment thinkers banned by the Inquisition but tacitly sanctioned for discussion among the illustrious minority in Spanish America by the modernising Bourbons. The few responses that have been identified consisted of refutations of his early argument that science and the arts had corrupted morality and that urban life was degenerate. ${ }^{13}$ He was probably of less interest to most creole readers in the 1780s than Adam Smith.

Rousseau acquired a distinctive and radical profile after the Revolutions in France and then - even more significantly for Spanish America - in Saint Domingue, where a victorious slave uprising in 1791, in which some 4,000 whites were killed, resulted eventually in the founding of the Republic of Haiti in 1804. The ramifications of these events were felt in a wave of slave revolts, especially in the River Plate (1795 and 1803) and in Venezuela (1795 and 1798), and a radical republican tradition among free peoples

12 Gabriel B. Paquette, Enlightenment, Governance, and Reform in Spain and Its Empire, 1759-1808(Basingstoke: Palgrave Macmillan, 2008).

13 There was no complete translation into Spanish of the Discourse on the Arts and the Sciences until 1910, although its arguments were known through refutations, such as Cristóbal Mariano Coriche's Oración vindicativa del honor de las letras y de los literatos (1763). 
of colour.14 Many creoles were therefore receptive to denunciations of Rousseau, such as the Mexican friar Servando Teresa de Mier's famous New Year sermon of 1791 attacking him for having inspired the Declaration of the Rights of Man.15 As often happens, Rousseau's detractors were some of his most important disseminators. For the generation born during the 1760s and 1770s, whose formative years spanned the course of the French Revolution, the reassertion of peninsular power in the colonies became increasingly unacceptable. For a radical minority of them, the Inquisition's edicts against Rousseau and other French authors only served to enhance their appeal. Certain centres became notorious for their discussion of the ideas of the philosophes, notably Caracas, Buenos Aires and the University of Charcas in Upper Peru. Moreover, Rea Spell has illustrated the extent of interest in Rousseau's ideas in late-eighteenth-century Spain. It was in this context that the Spanish intellectual José Marchena embarked upon translations into Spanish of most of Rousseau's works, starting with the Social Contractin 1799.16 A Spanish translation of the Discourse on the Origins of Inequality was also published in Charleston in 1803, stimulating the Inquisition to impose a specific ban on Rousseau's works, first in 1803 and again in 1808. Therefore, Rousseau was widely perceived as the most dangerous

14 David P. Geggus, ed., The Impact of the Haitian Revolution in the Atlantic World (University of South Carolina Press: Columbia, 2001); Aline Helg, Liberty and Equality in Caribbean Colombia, 1770-1835 (Univ. of North Carolina Press: Chapel Hill, 2004).

15 Adolfo Sánchez Vásquez,'La filosofía de Rousseau y su influencia en México', in Presencia de Rousseau (Mexico City: UNAM, 1962), 39-87, 74.

${ }^{16}$ His versions were published as Emilio, 1817; Julia, o, la Nueva Heloysa, 1820; and Discurso sobre el origen y los fundamentos de la desigualdad de condiciones entre los hombres, 1820. For an extensive bibliography of Spanish translations of Rousseau, see Rea Spell, Rousseau, 275-296. 
of all. His works travelled clandestinely through the Americas 'accompanied by a whiff of embers', an association which lent them 'huge subversive potential'; his very name became 'a message in itself, a virtual propaganda slogan against the old regime'.17 This was not only the case in the august private salons where restless young creoles excitedly discussed revolution under the ardent eye of 'Juan Jacobo',18 but also, far more dangerously, among other individuals from outside the elites. Inquisition documents from Mexico record that towards the end of the eighteenth century there was an increase in persecutions of 'minor officials, artisans, [and] soldiers'. ${ }^{19}$ Recent research has uncovered clandestine networks of urban discussion groups, based in shops, which covered a wide range of philosophy and political theory. ${ }^{20}$ And sermons were intended to be heard - and talked about - by a wide range of people. By 1808, the accumulated historical experiences of revolution and reaction, especially in France and Haiti, offered multiple models and possibilities for interpretation. In this mêlée, Rousseau's reputation, as created by both detractors and disciples - had already made him a touchstone of radicalism.

Once revolution had broken out in 1809 , an interest in ideologies shifted abruptly to an urgent need for ideas to help negotiate the new unforeseen and fast-moving situations. ${ }^{21}$

17 Juan Francisco Fuentes, José Marchena: Biografía política e intelectual (Barcelona: Editorial Crítica, 1989), 33 and 37-38.

18 Eduardo Ruiz, La librería de Nariño y Los Derechos del Hombre (Bogotá: Editorial Planeta, 1990), 141.

${ }^{19}$ Monelisa L. Pérez-Marchand, Dos etapas ideológicas del siglo XVIII en México a través de los papeles de la Inquisición, El Colegio de México, Mexico City, 1945, 89.

${ }^{20}$ François-Xavier Guerra, Annick Lampérière et al., Los espacios públicos en Iberoamérica (Fondo de Cultura Económica: Mexico, 1999).

21 Romero, 'Prólogo', xxii. 
New means of dissemination developed rapidly. Spanish America became a markedly transnational arena during these years, as the course of the independence struggle in any particular part of the region inevitably had implications for political decisions elsewhere. Many independence leaders spent time in exile, mostly in London or the United States, comparing developments, debating European responses to events throughout the Americas and exchanging information and experiences, ideas and texts. Within the territories, a new periodical press reached a far wider range of people than did books: the pioneering Aurora de Chile, for example, was widely sold on the streets and also read aloud. ${ }^{22}$ It is likely that popular theatre was also an important medium for transmitting images and ideas of Rousseau, at least in the River Plate and Chile, where most research has been done on the topic. Rousseau's own plays seem to have been rarely, if ever, staged in Spanish America whereas Voltaire's works were a standard part of the repertoire - but there were dramatisations of 'Juan Santiago' ${ }^{23}$ We also know that there were prominent actors and theatre directors who were interested in Rousseau and may have contributed to

22 Miguel Luis Amunátegui, Camilo Henríquez (Santiago: Imprenta Nacional, 2 vols., 1889), I:53-54.

${ }^{23}$ Raúl H. Castagnino, Esquema de la literatura dramática argentina (1717-1949) (Buenos Aires: Instituto de Historia del Teatro Americano, 1950); Eugenio Pereira Salas, Historia del Teatro en Chile desde sus orígenes hasta la muerte de Juan Casacuberta 1849 (Santiago: Ediciones de la Universidad de Chile, 1974). Neither of these works mentioned any performances of Rousseau's dramas, although it is at least possible that there was interest in his La découverte du nouveau monde. Pygmalion (1771) was probably the first of Rousseau's works to be translated into Spanish, from an Italian version, in 1783. There was a hostile play performed in the 1820s entitled Proceso de Juan Santiago en Sudamérica, by a cleric, Francisco de Paula Castañeda. 
publicising his ideas. ${ }^{24}$ The extent of popular dissemination itself was part of the context of how members of the elites responded to Rousseau's ideas.

\section{A radical social contract}

The provisional governments declared after Napoleon had deposed the Spanish monarch justified their existence on the principle of reversion of sovereignty to the people in times when the monarch was unable to govern, which had a long tradition in Spanish thought dating back to the thirteenth century. While Fernando VII still lived, the principle of reversion allowed for no permanent change in the relationship between Spain and its American lands. Creoles had a long list of grievances against colonial rule that were compellingly articulated in various statements of 1809-1811, but none of them necessarily entailed seeking political independence; they were compatible with restoration of monarchy and/or with liberal reform in Spain. The moderately liberal Cádiz Constitution of March 1812, which representatives from the Americas played a major role in drafting, addressed at least some of the creole demands, notably for free trade and for greater, albeit not equal, representation in the Cortes. As a result, many creoles showed signs of holding out for continued colonial rule from a reformed Spain over the uncertainties of independence.

In this context, which affected the whole region despite the specificities of the political dynamics in different places, Rousseau's arguments about the need for a newly

${ }^{24}$ For example, in the River Plate and Chile, the actor-director Luis Ambrosio Morante and the actor Juan Casacuberta. 
constituted political order to achieve liberty and allow for the expression of natural rights became crucial to the case of several key figures who advocated full independence. They had other sources of inspiration for the case against absolutism, or even colonialism. But it was only in Rousseau that they found the legitimating principles for moving from a critique of the old order to the foundation of a new one. ${ }^{25}$ The fervour for constitutionalism that characterised the independence struggles, especially during the early years, itself found inspiration in the Rousseauvian principle that the right laws would create a virtuous society (rather than Montesquieu's converse argument that laws should be shaped by existing custom and practice). Other thinkers had written about the social contract but only Rousseau conceptualised it as the basis for social transformation. For him, popular sovereignty was not just an abstract political concept but one with social and economic content, which could only function effectively in a political community with shared history and values. Such a conception of popular sovereignty was actually very different from that of the Spanish tradition, although advocates of independence strategically tended to take advantage of the potential for taking them both to refer to the same thing. The Spanish version assumed that 'el pueblo' would be constituted from local political bodies ('los cuerpos'), such as the municipal councils, in which there was democratic debate, but only by a select group of some social standing within the community. ${ }^{26}$ Rousseau's 'pueblo', in

25 Raúl Cardiel Reyes, Los filósofos modernos en la independencia Latinoamericana (Mexico City: UNAM, 1964), 121; Mario Dotta, El artiguismo y la revolución francesa (Montevideo: Fundación de la Cultura Universitaria, 1989), 78.

${ }^{26}$ Luis Villoro, 'Rousseau en la Independencia mexicana', 1981, Tiempo Cariátide, 55-61, 58, accessed October 2014 at www.uam.mx/difusion/casadeltiempo/80_sep_2005/55_61.pdf. 
contrast, conceptualised all individuals as citizens, equal before the law and equally bound to obey the law. It was no coincidence that creole politicians who were at least thinking ahead to the possibility of independence began to publish openly their own versions and accounts of Rousseau at this time. Versions appeared in Caracas, translated by José Vargas Vila, in 1809, and in Havana (one of the few places where the independence movement failed) in 1813.

The most important of these new publications was the edition of the Social Contract published in 1810 by Mariano Moreno (1778-1811), a key figure in the provisional government established after the Revolución de Mayo in Buenos Aires that same year.27 Moreno, who hoped for independence, declared the Social Contract to be the most important of the works of political theory that constituted 'the catechism of free peoples', arguing that anyone who read it 'would not easily be robbed of their rights'. In the prologue to his edition, he stated that he wanted everyone to read Rousseau so that they would understand their rights - and their obligations - as citizens of a republic. ${ }^{28}$ He ordered 200 copies for distribution in Buenos Aires schools, although soon after he was sent into exile the following year the Cabildo de Buenos Aires hastily sent them back to the printer and instead adopted a text by a monarchist priest. ${ }^{29}$ ‘Revolutions among men without

27 Del Contrato social o principios del derecho político (Buenos Aires: Real Imprenta de Niños Expósitos, 1810).

28 Mariano Moreno, 'Prólogo a la traducción del Contrato social' [1810], in his Escritos políticos y económicos, ed. Norberto Piñero (Buenos Aires: L. J. Rosso y Cía, 1915), 265-268.

${ }^{29}$ Ricardo Zorraquín Bécu, 'El Contrato Social y la Revolución de Mayo', in Catálogo de la exposición bibliográfica argentina de derecho y ciencias sociales (Universidad de Buenos Aires, Facultad de Derecho y Ciencias Sociales, 1960), 17-26, 21. 
enlightenment' could only end in 'disorderly horrors', Moreno argued, an example of which was provided by Spain, which - despite a fine display of heroism and sacrifice - had been unable to form a government that commanded legitimacy or a constitution to end anarchy, because 'the people were ignorant'. He emphasised the importance of 'each citizen' understanding 'the advantages of a constitution' that 'would restore to the people their rights' and protect them against 'new usurpations' of their sovereignty. He wanted 'each citizen' to regard 'the defence' of such a constitution 'as his own, personal good'.

Notoriously, Moreno omitted from his edition Book IV, chapter $8 \mid-$ on civil religion arguing in the preface that Rousseau 'talked utter nonsense about matters of religion'. 30 There has been some debate about Moreno's own views on religion, but whatever his personal creed, he would not have wished to provoke the Catholic authorities and thereby distract attention from what he saw as salutary in the rest of the text. As in other initiatives, such as the founding of a public library and a periodical, Moreno sought to prepare the people of Buenos Aires for liberty based on a modern concept of popular sovereignty. In an article in his Gaceta de Buenos Aires, he stated explicitly that: 'The bonds that unite the people to the king are different from those that unite men among themselves: a people is a people before it gives itself to a King $[s i c]^{\prime} \cdot 31$

Creole patriotism had existed for several decades as a cultural phenomenon without any significant political agenda. ${ }^{32}$ It was when the two were brought together that a compelling case for independence could be made, as can be seen in the early documents of

\footnotetext{
30 Moreno, 'Prólogo', 268.

31 Mariano Moreno, La Gaceta de Buenos Aires, 13 November 1810, 599-600.

${ }^{32} \mathrm{~A}$ lot of work has now been done on creole patriotism; the pioneer was David
} Brading, The First America (Cambridge: Cambridge University Press, 1991). 
Chilean independence, particularly the writings of the priest Camilo Henríquez (17691825). He was the first person to proclaim the need for independence, in January 1811, less than four months after a provisional government had been founded in Santiago on the principle of reversion. He did so by invoking both patriotism and philosophy. Seeking to move the arguments on from the claims of the natural law theorists, Henriquez argued that there was no natural law obliging provinces ruled by Spain in Europe and America to stay together; indeed, 'nature itself has formed them to live separately'. ${ }^{33}$ It was 'a geographical truth' that Chile was capable of independent existence both economically and culturally, he argued, given that it had both mineral resources and agricultural capacity, 'strong men' to work the land and navigate the sea, plus 'solid, profound and perceptive' minds who were 'capable of all the sciences and arts of genius'. Given the country's geography, with its natural borders of the Andes, the desert and the Pacific Ocean, did it not go against the very order of nature, he demanded, to be governed from overseas? ${ }^{34}$ Henríquez then built up his case by drawing upon philosophy, claiming that only the philosophers had 'dared to tell the people that they had rights and that they could only be governed ... under the conditions of a social pact'. 35 In an audacious act of intellectual appropriation that was characteristic of many such documents from the independence era, Henríquez claimed Aristotle for his cause. The human race would have been a great deal happier, he stated, had ecclesiastical scholars 'read in [Aristotle] the rights of man and the need to separate the three powers ... in order to conserve the liberty of the peoples', instead of wasting time over irrelevant

33 Camilo Henríquez, 'Proclama' (2 January 1811), in Romero, Pensamiento politico, vol. I, 220-224, 221.

34 Ibid., 221-222.

35 Ibid., 221 and 223. 
obscurities. ${ }^{36}$ Here Henríquez may have been deliberately reminding his audience of a passage on Aristotle in the Social Contract, with which he could have assumed at least some of them were familiar. Rousseau argued that Aristotle had mistaken 'the effect for the cause' in saying that some men were born for slavery and others for domination. For Rousseau, slaves were created by acts of oppression, which then changed their nature so that they were unable to resist their servitude: 'Slaves lose everything in their chains, even the desire to be rid of them; ... Force made the first slaves, their cowardice perpetuated them'. 37 It is a reasonable deduction that Henriquez, who was cautiously urging his compatriots to have the courage to claim their liberty, preferred to allow the practical consequences of his arguments to be concluded by allusion. Henriquez had been imprisoned by the Inquisition in 1809 , so he had good reason to be cautious about naming Rousseau openly, but he did mention 'Reynal'. In a conclusion ringing with Rousseauvian terms, he urged that 'patriotic virtue should unite with enlightened understanding' to 'break the chains of slavery' and fulfil 'the right of the peoples [and] the general will'. Both Father Miguel de Hidalgo (1753-1811), who launched an uprising in New Spain in 1810, and his successor and pupil, José María Morelos (1765-1815), were wellversed in French political thought. There is some debate in the historiography about whether Hidalgo, who was executed in July 1811, sought full independence for Mexico. What his public documents show is that, whether out of conviction or for tactical reasons,

36 Ibid., 223. Henríquez also discussed Aristotle in Rousseauvian terms in his 'Nociones fundamentales sobre los derechos de los pueblos', Aurora de Chile (Santiago), no. 1, 13 February 1812; also in Romero, Pensamiento politico, vol. I, 228-232.

37 SC, 43; OC III, 353.

38 Henríquez, 'Proclama', 223-224. 
he represented popular sovereignty as God-given to the king and only reverting to the people because Fernando had been dethroned. For example, in his Manifesto of 1811, he declared that the national congress he sought to convene would consist of 'representatives of all the cities, towns and places of this kingdom'. ${ }^{39}$ This was still the position that prevailed in late 1813: the Act of Independence declared at Chilpancingo stated that the Congress of Anáhuac there convened had 'recovered the exercise of the sovereignty usurped' because of 'the present circumstances in Europe'. ${ }^{40}$ By the time of the Constitution of Apatzingán, approved in October 1814, the restoration of Fernando and his rejection of the new political rights for Spanish Americans stipulated in the Constitution of Cadiz (1812), combined with other factors, had led to the radicalisation of the independence movement. In these altered circumstances, Morelos, who played an important part in drafting the Constitution, deployed a Rousseauvian ideal of sovereignty in order to further his aims. The revised conception was said to derive from 'all the citizens, voluntarily united in society', to reside 'originally in the people' and to be 'imprescriptible, inalienable and indivisible'. Rousseau's absolute concept is, however, diluted by a distinction between the origin of sovereignty in the people and 'its exercise in national representation' in a body of deputies elected by the citizens, in an attempt to negotiate the difficulties of reconciling

39 'Manifiesto en respuesta a la Inquisición', in J. E. Hernández y Dávalos, ed., Colección de documentos para la historia de la guerra de independencia de México de 1808 a 1821 (Impresor José María Sandoval: Mexico, 6 vols., 1877-82), vol. I, document 51.

40 'Acta de independencia de 6 de Noviembre de 1813', in Hernández y Dávalos, Colección de documentos, vol. 5, document no. 91. 
principles of sovereignty with practicalities of government. ${ }^{41}$ Even so, the idea of the inalienable sovereignty of the people has been traced through a series of Mexican constitutions to the document of 1917 , which remains in place today. ${ }^{42}$ By contrast, in most of the new republics, for example Argentina and Chile, sovereignty was invested in the nation, not the people. ${ }^{43}$

There is a good deal of evidence that in the first few years after 1808, the dominant understanding of sovereignty in Spanish America was drawn from a combination of the Spanish principle of reversion (which could be traced back to the Siete Partidas of Alfonso el Sabio through the works of Francisco Suárez) and theories of natural law theorists (drawn from Grotius and Pufendorf, sometimes through the lens of Jesuit interpreters).44 Most of the provisional governments were declared on that basis. However, it is less plausible to account for the subsequent moves towards founding independent republics without acknowledging that certain highly influential figures knew their Rousseau.

41 'Decreto Constitucional para la Libertad de la América Mexicana sancionado en Apatzingan á 22 de Octubre de 1814', in Hernández y Dávalos, Colección de documentos, vol. 5, document no. 183, quotations from 'Capítulo II: De la Soberanía', 704.

42 Antonio Colomer Viadel, 'La revolución francesa, la independencia y el constitucionalismo en Iberoamérica', in Leopoldo Zea, ed., América Latina ante la Revolución francesa (Mexico City: UNAM, 1993), 181-193, 185-187.

${ }^{43}$ For example, Chile: 'Sovereignty resides essentially in the Nation' (1822 and 1833); Colombia: 'Sovereignty resides radically in the Nation' (1830). In Argentina, there was no clause on sovereignty, but the preamble, echoing that of the United States, made an important change: 'We, the representatives of the people of the Argentine Nation', instead of 'We the people of the United States'.

${ }^{44}$ Chiaramonte, La Ilustración; Villoro, 'Rousseau'. 


\section{Equality: A radical legacy}

The independence wars were both a struggle against colonial rule and a series of local competitions for power, resources and legitimacy, some of which developed into struggles to liberate the dispossessed from elite oppression. There were 'rival visions of the future', with respect not only to economic development but also political institutions and the kind of society that was possible. 45 Those who wanted to pursue a more radical vision of what the new republics would look like found ideas, arguments, concepts and a language for articulating it in the work of Rousseau. A significant minority of the leaders of the early independence movements also agreed with him that liberty entailed equality. Thus Mariano Moreno, in late 1810, in a decree abolishing the privileges attached to certain official roles in colonial society, stated:

In vain would this government publish liberal principles to enable the peoples to enjoy the invaluable gift of their freedom, if we were to permit the continuation of those privileges, which to the shame of humanity tyrants invented in order to suffocate natural feelings ... If we wish the peoples to be free, let us religiously observe the sacred dogma of equality. 46

${ }^{45}$ For an overview of the historiography of independence, see Jeremy Adelman, 'Independence in Latin America', The Oxford Handbook of Latin American History, ed. José Moya (New York: Oxford University Press, 2011), 153-180, quotation at 159.

46 Junta Provisional [written by Mariano Moreno], 'Decreto sobre supresión de honores (6 December 1810), in Romero, Pensamiento politico, 285-289, 285 and 287. Noemí Goldman has rightly noted that there were limits to the egalitarianism envisaged by Moreno: Article 12 of the same decree stated that nothing should 'prevent the free entry to any public function' of 'respectable citizens' (Ios ciudadanos decentes). See her chapter 
In Mexico, the radical priest Morelos declared that the propertied classes were to pay for their complicity with colonial rule with all their wealth, which was to be confiscated and redistributed half to the poor, half to fund the military campaign. ${ }^{47}$ José Artigas (17641850) of Uruguay, a caudillo (military boss) who led the resistance against both the centralising claims of Buenos Aires and control by the Empire of Brazil, promoted the sovereignty of all the members of his Federal League, including the indigenous peoples. He maintained that they should not be kept separate in reservations but should play a full part in the government. ${ }^{48}$ His public speeches displayed familiarity with the ideas of popular sovereignty and the general will; they showed that by 1813 he had developed a coherent version of democratic republicanism to present to his constituency. ${ }^{49}$ Whether or not he read the Social Contracthimself - and he did have the education to do so - 'he had friends and advisers who could discuss [it] with him', and he evidently deemed the Rousseauvian language to be appropriate for attracting support. 50 He later implemented a land reform, decreeing that land was to be redistributed on the principle that 'the most unhappy will be

'Morenismo y los derechos naturales en el Río de la Plata', in Zea, América Latina ante la Revolución francesa, 151-167.

47 J. M. Morelos, ‘Plan Político: Medidas políticas que deben tomar los jefes para lograr sus fines por medios llanos y seguros, evitando la efusión de sangre de una y otra parte', Nov. 1813, in Romero, Pensamiento politico, II:56-57.

48 Dotta, El artiguismo, 95.

${ }^{49}$ José Artigas, 'Oración de Abril', 5 April 1813, in Romero, Pensamiento político, II:12-14.

50 John Street, Artigas and the Emancipation of Uruguay (Cambridge University Press: Cambridge, 1959), 177-178. 
the most privileged', 51 although the initiative was short lived because of the exigencies of war.

Some of the proclaimed egalitarianism was symbolic (which is of course not without its own significance) but a good deal of it took tangible form in the suppression of privileges, the ending of tribute and the abolition of slavery in most of the new republics during the 1820s (although it is argued that implementation of such policies was uneven).52 Some of the early advocates of independence, fearful that any concession to their opponents would result in defeat, went far further in promoting equality than Rousseau's texts entail. Their fears proved to be justified: the radical, Rousseau-inspired voices that rang out clearly above the confusion of the early stages of the independence struggles were drowned out - or extinguished - as the practicalities of trying to found states while fighting the Spanish enabled anyone threatened by an inclusive social contract to defend their own interests. Most of the creole politicians who oversaw the eventual victories of the independence movements were distinctly reluctant to extend Rousseau's uncompromising stance on liberty beyond a rejection of colonial rule: they regarded the rest of the populations, including most other creoles, as distinctly unfit even for negative freedoms, let alone Rousseau's positive ones. As is well known, liberals across Spanish America then spent many decades fighting against the resistance, both active and passive, of those who sought to preserve local versions of Spanish institutions, especially the

51 José Artigas, 'Reglamento provisorio de tierras', 1815, in Romero, Pensamiento político, vol. II, 24-26.

52 Slavery was legally abolished in Greater Colombia, 1821; Chile, 1823; Central America, 1824; Mexico, 1829; Uruguay, 1830; and Bolivia, 1831. In Argentina, it was 1853; Venezuela and Peru, 1854; Spanish colonial Cuba, 1886; and the Empire of Brazil, 1888. 
Catholic Church; liberalism only achieved sustained power, during the last few decades of the nineteenth century, at the expense of compromise with conservatism. The early independence leaders were severely criticised, especially by the nation-builders of the 1830s and 1840s, for trying to implement absolute principles in disregard of the actual conditions in which they were operating.

Yet the founding commitment to Rousseau's concept of the state as the manifestation and guarantor of liberty and equality before the law, that embedding of principles of equality within the body politic, had far-reaching consequences, the cumulative effects of which can be seen in the revised constitutions adopted across the region from the 1920 s to the 1940 s, nearly all of which included stipulations expressly committing the state to defending equality.

\section{The Americas as a source of regeneration}

The Spanish American reception of Rousseau's arguments about people in a state of nature has to be understood in the context of the long history of debates about indigenous peoples in the Americas, in which European commentary was only one part of a complex picture.53 As Peter Gay has noted, the term 'noble savage' cannot actually be found in Rousseau's work, ${ }^{54}$ nor does it seem to feature in Spanish American debate during the independence wars, although there were images close in spirit. Mostly, however, the debates took a

53 Jorge Cañizares Esguerra, How to Write the History of the New World(Palo Alto: Stanford Univ. Press, 2006).

${ }^{54}$ Peter Gay, 'Breeding is Fundamental: Jenny Davidson reflects on Enlightenment ideas about human perfectibility', Book Forum, April/May 2009, www.bookforum.com/inprint/016_1/3519, accessed August 2013. 
different turn. Some opponents of independence represented the Discourse on the Origins of Inequality as promoting primitivism in order to reject Rousseau's alleged elevation of natural man, arguing that only through reason could people attain virtue. At the same time, they quoted him out of context to support their contention that the pro-independence uprising presaged a return to a barbaric state of nature. ${ }^{55}$ Advocates of independence, on the other hand, avoided what Arthur Lovejoy characterised as the 'persistent historical error' that Rousseau was promoting primitivism in that text. 56 Rousseau's schema of humans as naturally good but corrupted by civilisation was read as an explanation for what some creoles saw as the corrupted state of the indigenous peoples - deprived of their natural liberty and thereby brought to ruin by the European conquerors. ${ }^{57}$ But what particularly attracted the attention of many independence supporters was Rousseau's idea of perfectibility. This, too, played out in several ways. In some cases, creoles appropriated to themselves the virtues of living without artifice or convention, comparing themselves favourably with their colonial masters. They could easily reconcile this with Christianity living the simple life, like Jesus. Independence leaders, who were acutely aware of the need to persuade potential supporters that fighting the Spanish was not a crime against Catholicism, adroitly blended Rousseau's arguments against monarchy with those attributed to God in the Book of Samuel, or lent the aura of Rousseau to their visions of

55 Sánchez Vasquez, 'La filosofía', 79.

${ }^{56}$ Arthur Lovejoy, 'The Supposed Primitivism of Rousseau's Discourse on Inequality', Modern Philology (Chicago), 21.2, Nov. 1923, 165-186, quotation at 165.

57 Cardiel Reyes, Los filósofos modernos, 121. 
Christian community liberated from the corrupting influence of Spain, by selectively citing his discussions of the simple life. 58

Other Spanish American republicans identified their own conditions with those that Rousseau saw as necessary to successful legislation of the general will but so rarely found: 'simplicity of nature linked with the needs of society'.59 These creoles felt that they had a great deal to learn from Europe in philosophy, literature and science, but not in politics, the despotism of which they believed themselves destined to replace with liberty and justice. The question of equality between Europe and the Americas was debated - both in Spain and in Spanish America - in political terms in the aftermath of the usurpation of Fernando VII; later, as independence movements attracted increasing support, it acquired a quasiideological dimension. A long history of Europe's projection of utopianism onto the Americas began to be refracted back in politicised form, in a version of americanismo that contrasted the uncorrupted state of nature in the Americas with the corruption of European society. At the Congress of Panama, in 1826, as Spanish Americans discussed a possible confederation of American states, the Peruvian delegate Manuel de Vidaurre echoed Rousseau's axioms on the state of nature in order to support claims that the peoples of the Americas were destined to realise the dream of human perfectibility. "The inhabitants of those parts of the Americas that were Spanish', he declared, 'restored to the state of nature, free and independent, in perfect possession of all their rights ... are more perfect than in the days after creation'. To the advantage of naturalness they could now add

58 José Amor de la Patria, Catecismo político Cristiano (selección), 1811, in Romero, Pensamiento politico, 212-219.

$59 S C, 78 ; O C$ III, 392. For Rousseau, such conditions actually existed only in Corsica (ibid.) and possibly in Poland. 
experience: 'Today, in complete control of all their faculties, they can distinguish the just from the unjust, the useful and agreeable from the pernicious and the annoying, the safe from the dangerous'.60 The Spanish American republics were ready, in short, to assume their world-historical role of regenerating civilisation: as beacons of liberty, toleration and equality at home - where the former 'oppressed African' would 'start to become rational in the realisation that nothing distinguished him from other men' - they would promote peace and open exchange abroad.61

One compelling example can be seen in a play by Camilo Henríquez: La Camila, o la Patriota de Sud-America (1817), which was performed in Buenos Aires (although not, apparently, in Chile). ${ }^{62}$ The action takes place a few months after the defeat by Bonapartists of the first declaration of independence from Spain, made in Quito in August 1809. The author included a foreword in which he briefly described a documented incident when loyalist troops from Lima went on the rampage in Quito, killing about 500 people, in revenge for the murder of one of their own captains. 63 The play is set in a village in the Ecuadorian jungle, which is represented as a utopian space where the true nature of the humans who enter it is revealed. In this setting, the Spanish are referred to (there are no

${ }^{60}$ Manuel L. de Vidaurre, 'Discurso en el Congreso Americano de Panamá', 22 June 1826, in Germán A. de la Reza, ed., Documentos sobre el Congreso Anfictiónico de Panamá (Caracas: Fundación Biblioteca Ayacucho, 2012), 184-190, quotations at 184.

61 Ibid., 186-187.

62María de la Luz Hurtado, Teatro chileno y modernidad: Identidad y crisis social (Irvine, CA: Ediciones de GESTOS, 1997), 47; Castagnino,Esquema, 29.

${ }^{63}$ Camilo Henríquez, 'La Camila, o, La patriota de Sud-America', in Amunátegui, Camilo Henríquez, II:309-352, 311. Page references to the subsequent quotations in this paragraph are given in brackets. 
Spanish characters) as cruel and superstitious, their way of life 'in contradiction with nature' (324). The Omagua are portrayed as cultured people who combine the virtues of civility, some of which they have acquired from the creoles, with the compassion of people living in harmony with nature (cf. Rousseau's pitie). The chief's house is 'decorated to English taste' (334) and he has studied modern political thought in the United States, which Henríquez, here and elsewhere, represented in utopian terms. The creoles are tainted by their support for the misdeeds of the Spaniards, but those that have encountered modern Enlightenment ideas have the possibility of redemption through contact with these indigenous Americans who know how to reconcile nature and culture. The main character, Camila, a young creole woman, and her parents have fled the royalist atrocities in Quito, in which they fear her husband has been killed. They are brought before the chief of the Omagua people, who are referred to throughout as 'Americans'. He feigns lack of sympathy, telling them that there is no reason for him not to hand them over to the Spanish, and reminds the creole family of their forebears' complicity in Spanish repression, not least in the failure to protest against the murder of Tupac Amaru. His words provoke deep repentance in Camila and prompt her to declare that 'if America ... did not adopt more liberal principles, it would never escape from the sphere of Spain overseas, [which was] impoverished and ignorant like European Spain' (346). When she reappears dressed in indigenous clothing to symbolise her newfound distance from the Spanish, the chief proclaims her a 'heroine of the new world' (351). Reunited with her husband, who has also found safe haven with the Omagua, she is reassured: 'here there are no tyrants, no persecutors. You are in the sanctuary of liberty, among the people of reason and of nature ... here we are building the foundations of a new Philadelphia' (350). Thus Rousseau's 
conception of the relationship between nature and culture was adapted by Henríquez to dramatise the potential to realise a modern utopia in the Americas.

\section{Archetype of an intellectual: The writer as agent of social transformation}

Mariano Moreno wrote an Apotheosis of Rousseau, which encapsulated the appeal of Rousseau's practice as an author: fierce intelligence complemented by a highly developed sensibility, a vivid and brilliant imagination, a commitment to truth, a vast range of knowledge and moral courage. This portrait contrasted starkly with his Apotheosis of Voltaire, which was a far more prosaic piece that merely reported his entry into the Panthéon.64 Rousseau's self-description as an ancient in modern dress was often cited approvingly in Spanish America, where the claim to be the modern inheritors of ancient greatness was given political expression in republicanism long before it acquired a cultural dimension in 'Latinity'. Rousseau's arguments about the poverty of philosophy lent a modern edge to views already held by many Spanish American thinkers: that reason alone was not sufficient for virtue; that emotion had to be part of the exemplary life; and that truth had an ethical as well as logical dimension. There has been enduring interest in

${ }^{64}$ Mariano Moreno, Artículos que la "Gazeta” no llegó a publicar, ed. Eduardo Durnhofer (Buenos Aires: Casa Pardo, 1975), 65-70 and 43-50 on Rousseau and Voltaire respectively. Moreno published a summary of this account of Rousseau's life as exemplary in his 'Prólogo al Contrato social', 1810, 267-268. 
Spanish America in Rousseau's life as exemplary of the struggle between reason and emotion.

During the independence wars, particularly during the early stages when everyone in public life seemed to be drafting proclamations and prescriptions for the new political order, there was particular interest in Rousseau's strategies for successful authorship, which meant that his books could function not only as political statements but also as political acts. His literary style - clear, vigorous, passionate and accessible - was widely admired, even by those who spurned his ideas. Style has had a particularly important place in Spanish American cultural history and most commentary on Rousseau's works in Spanish America has celebrated the brilliance of his writing and his knack for creating unforgettable images. But Spanish American publicists were also intrigued by Rousseau's skill in creating a persona, cultivating his own celebrity and managing his reputation. 66 So far as we know, The Confessions was not translated into Spanish until 1869, so biographical information about Rousseau must have been disseminated, at least initially, by educated Spanish Americans who read French. Tales of his persecution were certainly well known. One Chilean supporter of independence recalls that they all felt compelled to learn by heart the 'Profession of Faith of a Savoyard Vicar', ${ }^{67}$ particularly after a Spanish

${ }^{65}$ Del contrato social, ed. Mariano Ruiz-Funes (Mexico City: Biblioteca Enciclopedia Popular, 1945).

${ }^{66}$ Antoine Lilti has argued that Rousseau's specificity was to claim that the value of his philosophy relied on his own authenticity, a claim that is borne out by Spanish American responses. More on this point in Lilti's article 'The Writing of Paranoia: JeanJacques Rousseau and the Paradoxes of Celebrity', Representations 103 (2008), 53-83.

${ }^{67}$ José Zapiola, Recuerdos de treinta años: 1810-1840 (Santiago: Imprenta de El Independiente, 1872-1874), ch. III. 
translation of Émile came out in 1817.68 As a new public stage opened up during the wars of independence, Rousseau provided a model of how to act upon it.

Over the last two centuries, Rousseau has often been invoked in Spanish America, particularly by revolutionaries, as an exemplary intellectual: politically engaged, passionate in the pursuit of truth, upholding the public responsibility of the writer by refusing to publish anonymously. In Spanish America, then, there was a more politicised version of the European reading of him as theorist of individual authenticity: not only did the philosopher's claims have to be founded in personal authenticity, but also the politician's. Famously, Che Guevara carried the Social Contract on his campaigns. Slavoj Zizek has a short section entitled 'Guevara as a Reader of Rousseau' in his Living in the End Times, in which he cites a passage from Guevara's Man and Socialism in Cuba that he sees as echoing what Che took from Rousseau: 'the revolutionary leaders must have a large dose of humanity, a large dose of a sense of justice and truth in order to avoid falling into dogmatic extremes, into cold scholasticism, into isolation from the masses' ${ }^{69}$ Images of Rousseau created during the wars of independence had a lasting impact on Spanish American ideas about what being an intellectual entailed, not least the conviction that cultural practice could be a route to political freedom.

68 Emilio, ó De la educación, trans. J. Marchena (Burdeos: Imprenta de Pedro Beaume, 1817).

${ }^{69}$ Slavoj Žižek, Living in the End Times (London: Verso, 2010), 108; Ernesto Che Guevara, Man and Socialism in Cuba, trans. Margarita Zimmermann (Havana: Book Institute, 1967), 44. 


\section{Conclusion}

Rousseau's ideas had consequences in Spanish America, despite - or perhaps because of being taken out of context, reinterpreted and reconfigured to meet the urgent challenges of anti-colonial wars. No other thinker offered such a compelling justification to the provisional juntas for making the leap from being caretakers of monarchical sovereignty to defenders of popular sovereignty. After the first declarations of independence a strong dose of voluntarism was required to keep the republican ideal alive, and for a significant number of prominent figures, that voluntarism drew inspiration from Rousseau. There were also far more lasting consequences. Because Rousseau was available as a source of ideas and inspiration, principles of equality were embedded in the political cultures of the new republics, Americanismo acquired a political charge, and a particular ideal type of intellectual took hold. Thus his significance lay less in the areas of constitutionalism or public policy than in a more diffuse but nonetheless powerful impulse towards a particular conception of the relationships between state and society and between politics and culture. That the enlightenment of the citizenry was a public responsibility, that culture could be liberating, that intellectuals could change the world, were all ideas embedded in the mainstream political discourse of Spanish America throughout the nineteenth and most of the twentieth centuries. When later reformers and revolutionaries looked back to the early leaders of independence to find inspiration and legitimation for their own plans to bring about more equal societies, they found a powerful legacy of republican projects based on a radical social contract. José Martí, for example, leader of the Cuban independence at the end of the nineteenth century, elaborated a radical liberalism based on the idea of 
authentic natural man linked to self-affirmation and self-government for the whole of Latin America. Rousseau is by no means the only reason, but the ubiquity of his presence in the public debates of the founding era of these republics is one significant factor in the explanation.

It has only been possible to highlight here a few of the many different ways in which Rousseau was read in early nineteenth-century Spanish America. Nonetheless, these examples are a telling illustration of what can happen when ideas travel from one context to another, radically different one, especially perhaps the ideas of a writer with as much political baggage as Rousseau had acquired by 1808. The context for understanding how Rousseau was interpreted in Spanish America goes beyond the other texts alongside which he was read; beyond the means by which his ideas were disseminated; and beyond even the institutions where they were debated, important although each of these three elements is, to include the political and social dynamics of the independence wars. The initial success of independence leaders in translating Rousseau's principles of natural liberty and equality into laws (even if they were superseded or, at best, patchily implemented) upped the stakes of the wars for all creoles. In these charged circumstances, many parties to the arguments about a possible new political order appropriated Rousseau for their own purposes, often to define their position in relation to opponents. In doing so, they were only doing what many of Rousseau's European commentators did, not to mention Rousseau himself: instrumentally plucking out historically rooted examples to test out general principles, combining an aspect of one problem with that of another, arguing or citing 
against the grain and, sometimes, simply making things up. ${ }^{70}$ This does not mean that there was a limitless variation on the meanings of Rousseau's texts: the principles he articulated were attractive not least because they seemed unchanging and universal. It does mean, however, that Rousseau's place in Spanish American intellectual history cannot be understood in terms of his 'influence', which is shorthand for assuming that his ideas travelled and remained intact. Instead, we have to think in terms of the interaction between the ideas and their new contexts, which can include social and political practices as well as other texts. As historians, we, too, need both Rousseau and Montesquieu.

70 Valentina Arena, for example, notes that much of Rousseau's statistics about the Roman Republic were fictional, and that his account of the political institutions was highly idiosyncratic given the historical sources he used (Arena, 'The Roman Republic of JeanJacques Rousseau', History of Political Thought, forthcoming). 